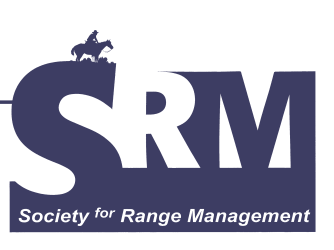

\title{
Natural Resources Conservation Workshop for Arizona Youth
}

\section{By Kim McReynolds}

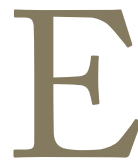

ach summer, a group of high-school students and natural-resource professionals pack up and head to the mountains of Arizona to spend a week together learning about the diverse resource base of the state. The Natural Resources Conservation Workshop for Arizona Youth (NRCWAY) provides students with an opportunity for handson learning in the field and professionals with the hope that some of the students will choose careers in natural resource fields. What the students don't expect are some of the life-long friendships that are formed, the professional connections that are made during the week, and a new respect for differing opinions.

The development of the NRCWAY dates back to the 1950s. At that time, the Arizona Association of Conservation Districts (AACD) learned of youth camps in other states and

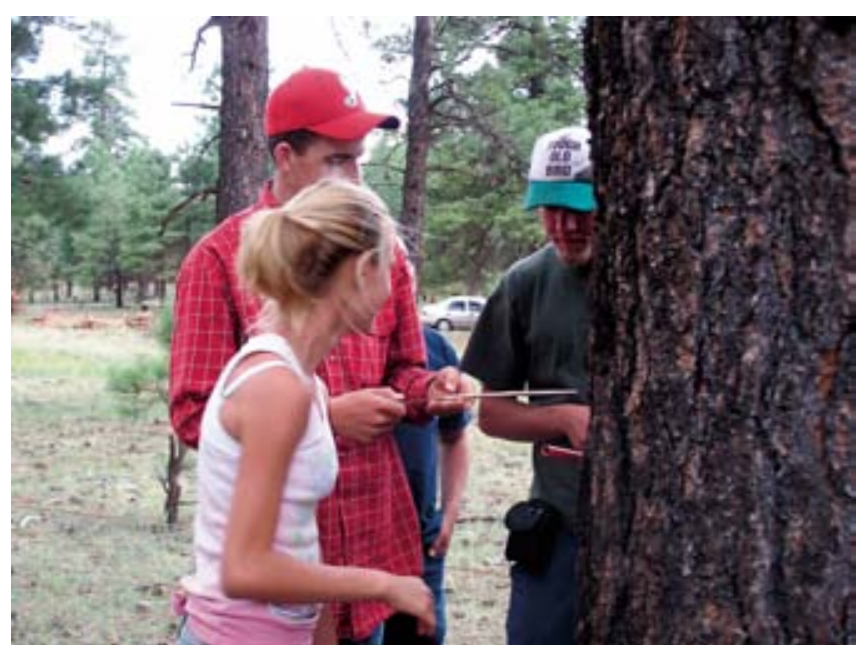

Core sampling a tree to find its age. Photo courtesy of Susan Pater. began developing plans for one in Arizona with help from the Arizona State Land Department and the University of Arizona. The first workshop was held in 1962 as a boys-only range and livestock management camp on the San Carlos Apache Reservation. This was a true outdoor experience complete with tents, cutting wood for the fire, and chuckwagon cooking. The workshop has moved to different locations with established facilities around the state since then and started accepting female participants in 1974. The Arizona Section, Society for Range Management, took over the role of planning and implementing the workshop in 1975.

Since SRM's direct involvement, the NRCWAY has been a program designed to introduce the concepts of naturalresource management to high-school age youth. Approximately 40 outstanding students who have expressed an interest in environmental issues have been selected each year to attend the workshop. The week-long program provides hands-on training in such areas as basic ecology, geology of Arizona, wildlife ecology and management, forestry, range management, soils, water resources, recreation, and watershed management. The program varies from year to year, depending on location, instructor availability, and current issues (ie, prolonged drought, wildfire threats, massive outbreaks of insects and related tree mortality). Instructors include professionals directly involved in resource management from private industry, state and federal agencies, and Arizona's universities.

The goal of the NRCWAY is to introduce students to different disciplines of natural resources and career opportunities. Program objectives focus on the students learning that 1) natural resources are sustainable, 2) all land-management activities and natural resources are interrelated, 3) management decisions are made based on science, and 4) the public 


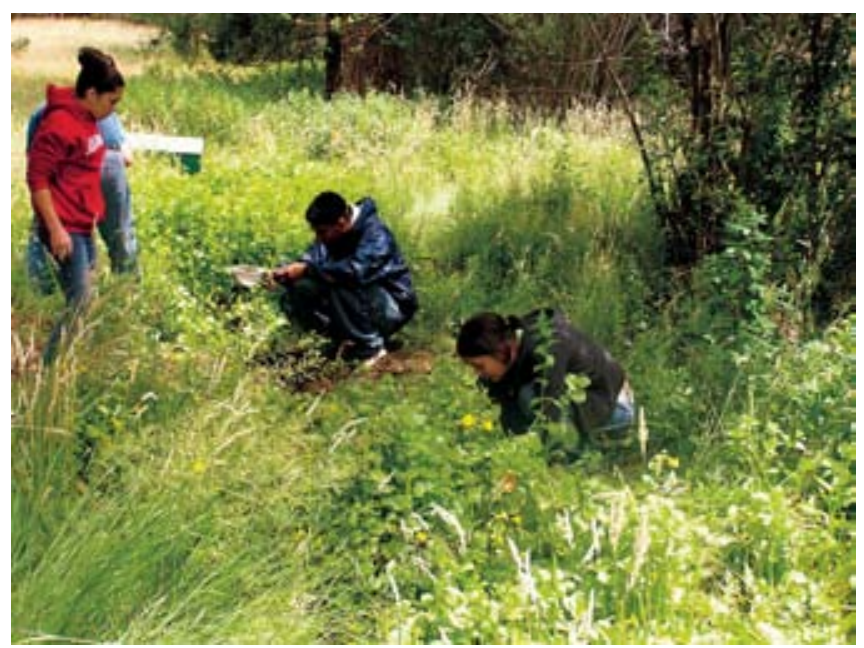

Looking for aquatic insects in a stream. Photo courtesy of Susan Pater.

(students included) have a voice in management decisions.

In 2000, the Arizona Section applied for and received a grant to conduct a survey of former workshop attendees to determine what impact the workshop had on them related to the stated objectives. The study included a sample of former students from a 20-year period-1979 to 1999 . Finding the students was a difficult task. A total of 43 former students participated in both a phone interview and a follow-up written survey. They were grouped in 5-year increments in order to look at differences in those who had attended recently (still in high school or college) vs those who had attended in earlier years. Although responses varied when asked what they remembered most about NRCWAY, the largest percentage answered: the instructors, meeting interesting people, the workshop location, and field trips. All but 2 of the respondents stated that the workshop gave them the basis to make more informed choices regarding natural-resource issues. Former students were also asked about their schooling and occupation to determine how many had entered the field or were studying toward a degree in natural resources. Seventeen individuals had either gone into fields or were majoring in areas such as forestry, recreation, range management, watershed management, and wildlife biology. Careers ranged from an attorney for a federal land-management agency, to field professionals, such as a soil scientist, to 1 individual who was the head of a state agency with natural-resource responsibilities. One unsolicited comment returned with the written survey stated, "The single most important thing I gained from NRCWAY was the well-rounded general knowledge about how all our natural resources are linked together. Now that I'm a parent, I'm even more grateful for the program because of the wealth of knowledge I get to pass along to my kids! I can just see the wheels turning in their minds when we're outside playing and I take a moment to tell them a fact or two on whatever topic seems appropriate at the time. Every day offers countless opportunities to teach them about natural resources! Thanks!"

One aspect of the workshop that can be seen, but not easily measured, is the change in attitude with respect to listening to opposing views. This has become more apparent as the student base has changed from largely rural, farm- and ranchbased students to urban students with no direct tie to the land. One such encounter between the 2 groups stands out in many of the instructors minds. The mix of students that particular year included 1 girl from a very rural, traditional ranching family and another who wore only tie-dyed clothes and belonged to Earth First! One evening, the wrap-up discussion was on range management and livestock grazing. Heated discussion on the benefits and destruction caused by livestock grazing continued for quite a while, with many of the other students choosing sides with the main 2 debaters. As the discussion was about to end, the girl from the ranching family stood up and faced the other girl. She said that, though she still did not agree with her position against livestock grazing, she did respect her for listening to the other side of the issue. Then the second girl stood and said that, although she did not like cattle grazing, she now understood that at least some ranchers cared about the environment. It was a great lesson for everyone, students and instructors alike.

The year 2005 marks the 43rd year since the first NRCWAY. Unfortunately, there were not enough applicants to hold the workshop this summer. Numbers have been steadily dwindling for the last 10 years. Marketing and recruiting strategies this year included lowering the age limit to include junior high and lower high-school age students and introducing more technology related to natural resources, such as GPS and GIS applications.

Just as times have changed NRCWAY from an all boys range and livestock camp to a coed natural-resources workshop, times are changing again. The NRCWAY is at a crossroads, and the Arizona Section will be determining what future direction to take.

The author is Area Extension Agent and Regional Specialist, Natural Resources, University of Arizona, Cooperative Extension, Willcox, Arizona, and former President of the Arizona Section SRM. 